\title{
Uji Coba Pembuatan dan Strategi Pemasaran Dodol Berbahan Dasar Labu Siam
}

\author{
[Experiment and Marketing Strategy of Dodol Made of Chayote] \\ Dewi Andriani ${ }^{1)}$, Nila Sartika Achmadi ${ }^{2)}$, Andi Azizah Ramadhani ${ }^{3)}$ \\ 1)Program Studi Perhotelan, Politeknik Bosowa \\ 2) Program Studi Perhotelan, Politeknik Bosowa \\ 3)Program Studi Perhotelan, Politeknik Bosowa
}

\begin{abstract}
Chayote is a local vegetable with high nutrient which is sold with low price. Chayote can be produced into dodol with the following steps: sorting, peeling, cutting, washing, mashing, and then processing chayote into dodol. This research aims to find out how to measure people's acceptance of chayote dodol and how to market it. This is an experimental research on how to make chayote dodol and descriptive research to describe the best marketing strategy to introduce chayote in the market. The population is students of Bosowa Polytechnic where 73 of them were chosen to become the sample to test the taste, color, scent, and texture of chayote dodol. There were three treatments: LS1 (100\% chayote), LS2 (75\% chayote), and L3 (50\% chayote). Data was analyzed with descriptive statistic from Hedonic Test. The highest average score from the scent treatment was LS1 with 3.31 out of 5 score. From the taste, the respondents mostly chose LS1 with 2.88 average score. From the color, the respondents mostly chose LS2 with average score of 3.01. The last aspect was texture and mostly respondents chose LS1 with 3.00 average score. Based on the result, this research used 4Ps marketing strategy to introduce this product to the market.
\end{abstract}

Keywords: dodol, chayote, hedonic test, marketing strategy

\begin{abstract}
ABSTRAK
Labu siam adalah sayuran local yang memiliki nutrisi tinggi tetapi dijual dengan harga rendah. Labu siam dapat dibuat menjadi dodol dengan langkah-langkah sebagai berikut: pemilihan, pengupaan, pencucian, penghancuran, dan pembuatan dodol dari labu siam. Peneltian ini bertujuan untuk mengetahui daya terima amasyarakat terhadap dodol labu siam menjadi dodol dan bagaimana memaarkan produk tersebut. Penelitian ini merupakan penelitian eksperimen untuk mengetahui pengolahan labu siam menjadi dodol dan penelitian deskriptif mengenai strategi pemasaran bagi dodol labu siam. Populasi terdiri dari mahasiswa Politeknik Bosowa dengan 75 orang dia antaranya dipilih sebagai sampel untuk menguji rasa, warna, aroma, dan tekstur dodol labu siam. Terdapat tiga perlakuan yaitu LS1 (100\% labu siam), LS2 (75\% labu siam), dan LS3 (50\% labu siam). Data dianalisis dengan statistic deskriptif dari Uji Hedonik. Nilai rata-rata tertinggi dari segi aroma adalah LS1 dengan skor 3,31 dari skor maksimum 5. Dari segi rasa, responden kebanyakan memilih LS1 dengan nilai rata-rata 2,88. Dari segi warna, responden kebanyakan memilih LS2 dengan nilai rata-rata 3,01. Aspek terakhir adalah tekstur dan kebanyakan responden memilih LS1 dengan nilai rata-rata 3,00. Berdasarkan hasil ini, digunakan strategi 4P untuk memperkenalkan produk ini di pasar. Rumasan masalah ini adalah untuk mengetahui daya terima masyarakat terhadap dodol labu siam, dan mengetahui strategi pemasaran untuk memperkenalkan dodol labu siam.
\end{abstract}

Kata Kunci: dodol, labu siam, uij hedonic, strategi pemasaran 


\section{PENDAHULUAN}

\section{1) Latar Belakang}

Sulawesi Selatan adalah Provinsi yang memiliki berbagai macam sayuran dan buahbuahan, hampir dapat ditemukan di berbagai daerah di Sulawesi Selatan oleh karena itu masyarakat dapat memanfaatkan aneka hasil pertanian dan perkebunan tersebut sebagai bahan pangan sehari-hari, termasuk sayur-sayuran yang beraneka ragam sebagai pelengkap kebutuhan nutrisi dalam tubuh. Beberapa jenis sayursayuran yang memiliki kandungan gizi yang dibutuhkan dalam tubuh seperti labu kuning yang memiliki kandungan gizi yang cukup seperti kalori, vitamin A, yang bermanfaat untuk penurun panas jika mengalami demam, labu siam sendiri memiliki kandungan gizi seperti vitamin A dan C, kalsium, kalori, saponin sangat bermanfaat dalm menghambat dan mencegah stroke, mencegah kanker, dan menurunkan tekanan darah (Mahmud, 2014). Sayur-sayuran tersebut sangat mudah didapatkan dan harga yang sangat relatif murah salah satunya adalah labu siam.

Labu siam (sechium edule) adalah tanaman subtropis dan termasuk spesies cucurbitaceus yang sering digunakan sebagai bahan makanan. Tanaman ini berasal dari Meksiko dan telah dibudidayakan sejak zaman pra-Kolombia. Labu siam salah satu komoditas yang sangat mudah ditemukan, hal ini sesuai dengan data statistik yang menyatakan bahwa produksi labu siam dari tahun ke 2009 hungga tahun 2015 mengalami peningkatan yaitu dari 321.023 ton menjadi 428.197 ton (Badan Pusat Statistik, 2015:71) (Statistik, 2015). Buah ini memiliki ciri Labu siam memiliki batang lunak, beralur, banyak cabang, terdapat pembelit berbentuk spiral, kasap dan berwarna hijau. Bunga dari labu siam berwarna kuning dengan putik satu. Labu siam berakar tunggang, berwarna putih kecoklatan. Buah berukuran agak lebih besar dari kepalan tangan, berbentuk membulat ke bawah, ada alur pada kulit luar yang agak mirip dengan pembagian ruang dalam buah,
Daun berbentuk jantung, tepi bertoreh, ujung meruncing, pangkal runcing, kasap, panjang 4-25 $\mathrm{cm}$, lebar 3-20 cm, tangkai panjang, pertulangan menjari dan berwarna hijau, Sedangkan biji berbentuk pipih, berkeping dua dan berwarna putih (riana, labu siam, 2010). Labu siam merupakan jenis sayuran yang memiliki daya awet yang tinggi serta merupak sumber vitamin A kaya dengan karoten dan memiliki kandungan gizi yang begitu lengkap yang dibutuhkan oleh tubuh

seperti yang dijelaskan sebelumnya oleh penulis kandungan gizi labu siam dalam 100 gram daging labu siam seperti kalori 26-31 kkal, gula larut air $3,30 \%$, protein $1 \%$, lemak $0,3 \%$, karbonhidrat $7,7 \%$, serat $1 \%$, hemiselulosa 7,55 $\mathrm{mg}$, selulosa $16,42 \mathrm{mg}$, lignin $0,23 \mathrm{mg}$, natrium 36 $\mathrm{mg}$, kalium

*Korespondensi Penulis:

E-mail: dewi.andriani@bosowa.co.id

3378,62 mg, magnesium $147 \mathrm{mg}$, alkaoid 1,57 mg,polifenol 5,93 mg, kalsium $19 \mathrm{mg}$, fosfor 30 $\mathrm{mg}$, seng $2,77 \mathrm{mg}$, mangan $0,38 \mathrm{mg}$, besi $0,6 \mathrm{mg}$, tembaga $0,25 \mathrm{mg}$, vitamin A $5 \mathrm{mg}$, vitamin C 5 $\mathrm{mg}$, thiamin $0,03 \mathrm{mg}$, riboflavin $0,04 \mathrm{mg}$, niasin $0,5 \mathrm{mg}$, asam askorbat $20 \mathrm{mg}$, saponin 1,65\%, flavonid $0,95 \%$, proantosianin $75,73 \mathrm{mg}$, adapun beberapa manfaat dari kandungan gizi seperti dapat menurunkan kadar glukosa darah, mengahmbat dan mencegah penyerapan kolestrol dalam tubuh, mampu mempelancar peredaran darah sehingga dapat mencegah stroke, menurunkan resiko jantung, menurunkan tekanan darah, membantu cegah kanker, dan membantu proses inflamasi (riana, 2010).

Labu siam memiliki tekstur lebih mudah diolah dan tidak perlu memutuhkan waktu yang lebih lama untuk dimasak, labu siam sendiri banyak diolah sebagai sayur untuk makanan pokok masyarakat, kali ini penulis ingin membuat inovasi baru untuk sayur labu siam karna dari bahan yang mudah didapatkan, tesktur 
yang mudah diolah, harga yang relatif murah, dan bahan tersebut hanya dikelola masyarakat sebagai sayur.

Dodol merupakan makanan tradisional yang cukup banyak diminati masyarakat dan sejak zaman dahulu yang diolah dengan cara tradisional. Saat ini dodol mempunyai nama setiap daerah seperti, dodol garut, dodol kudus, gelami dari sumatra utara, dodol durian dan lempong, dari kalimantan dan sumatra. Dodol termasuk olahan setengah basah yang padat dan kenyal, produk sejenis yang dibuat secara tradisional disebut jenang dengan tekstur yang lembek dan berminyak (fatma, 2015). Saat ini dodol dijadikan ciri khas dari beberapa daerah dengan rasa yang berbeda.

Menurut Standar Nasional Indonesia (SNI) nomor 01-2986-1192, dodol adalah produk makanan yang dibuat dari tepung ketan, santan kelapa, dan gula atau tanpa penambahan bahan makanan dan bahan makanan yang diizinkan, dan mempunyai tekstur lunak, mempunyai sifat elastis, dapat langsung dimakan, tidak memerlukan, pendinginan dan juga cukup kering sehingga dapat stabil dalam penyimpanan ((SNI), 2015).

Seiring perkembangan dodol mempunyai beraneka rasa seperti dodol nanas, durian, sirsak dan mangga yang terbuat dari buah-buahan segar sedangkan dodol tradisional tetap mempertahakan rasanya yang belum menggunakan essense atau penambah rasa, dodol tersebut terbuat dari tepung antara lain tepung ketan, santan, dan gula.

Di masyarakat sendiri telah banyak beredar berbagai macam dodol yang telah diinovasi, diantaranya dodol buah-buahan, sayursayuran, dan maupun dodol tradisional. Hampir semua jenis buah-buahan dan sayur-sayuran dapata diolah menjadi, dodol yang dihasilkan tergantung jenis sayuran yang digunakan. Tujuan dari pengolahan labu siam menjadi dodol bertujuan untuk memeperpanjang daya simpan sayur dan di lain sisi memberikan inovasi baru kepada masyarakat tentang pengolahan labu siam dengan kandungan gizi yang banyak baik untuk kesehatan tubuh.

2) Identifikasi Masalah

Berikut adalah identifikasi masalah dari penelitian ini:

1) Bagaimana daya terima masyarakat terhadap dodol labu siam dinilai dari segi rasa, aroma, warna dan tekstur?

2) Bagaimana strategi pemasaran untuk memperkenalkan dodol labu siam?

c. Tujuan dan Manfaat Penelitian

Penelitian ini bertujuan untuk: 1) mengetahui daya terima masyarakat terhadap dodol labu siam, dan 2) mengetahui strategi pemasaran untuk memperkenalkan dodol labu siam.

Manfaat dari penelitian ini adalah: 1) memperkaya pengetahuan masyarakat tentang nilai gizi yang terkandung dalam labu siam, 2) memberikan inovasi baru kepada masyarakat untuk mengonsumsi sayur labu siam dengan rasa yang enak dan tetap bergizi. 3) Bagi peneliti selanjutnya diharapkan dapat dijadikan sebagai referensi atau bahan acuan

\section{METODE PENELITIAN}

\section{Jenis Penelitian}

Penelitian ini merupakan penelitian eksperimen untuk mengetahui cara pengolahan labu siam menjadi dodol dan daya terima masyarakat terhadap dodol labu siam.

\section{Metode Penarikan Sampel}

Teknik pengumpulan data dilakukan melalui pembagian angket kepada seluruh panelis. Sedangkan teknik pengambilan sampel yang digunakan dalam penelitian ini adalah non probability sampling yaitu incidental sampling. Populasi yang digunakan pada penelitian ini adalah seluruh mahasiswa Politeknik Bosowa 
Angkatan 4 dengan total sampel sebanyak 73 orang.

\section{Alat dan Bahan}

Alat yang digunakan dalam proses pembuatan dodol berbahan dasar labu siam adalah blender, sendok, mangkok, baskom, pisau, dan kompor. Sedangkan bahan yang digunakan adalah labu siam, gula dan garam.

\section{Metode Analisis Data}

Analisis data yang digunakan dalam penelitian ini adalah statistik deskriptif. Setelah nilai rata- rata ditemukan, langkah selanjutnya yaitu melakukan pemberian nilai kriteria. Adapun kriteria penilaian yang dimaksud (Sugiyono, 2016 : 147) adalah sebagai berikut :

1) $0-0,9$ sangat tidak suka

2) 1,0 -1,9 tidak suka

3) 2,0 - 2,9 kurang suka

4) 3,0 - 3,9 suka

5) 4,0 - 4,9 sangat suka

Setelah pemberian kriteria penilaian dilakukan, langkah selanjutya adalah menganalisis data dengan menggunakan statistik deskriptif. Pada penelitian ini, menggunakan statsitik deskriptif dalam bentuk penyajian data dengan menggunakan tabel dan diagram batang untuk menarik kesimpulan mengenai daya terima masyarakat terhadap dodol berbahan dasar labu siam. Sehingga melalui cara tersebut dapat memudahkan pembaca untuk mengetahui hasil dari penelitian ini.

Data dianalisis menggunakan metode statistik deskriptif dengan membandingkan nilai rata-rata setiap perlakuan. Data ini diperoleh berdasarkan hasil Uji Hedonik atau uji kesukaan untuk mengetahui daya terima masyarakat terhadap dodol labu siam.

\section{HASIL DAN PEMBAHASAN Daya Terima Masyarakat}

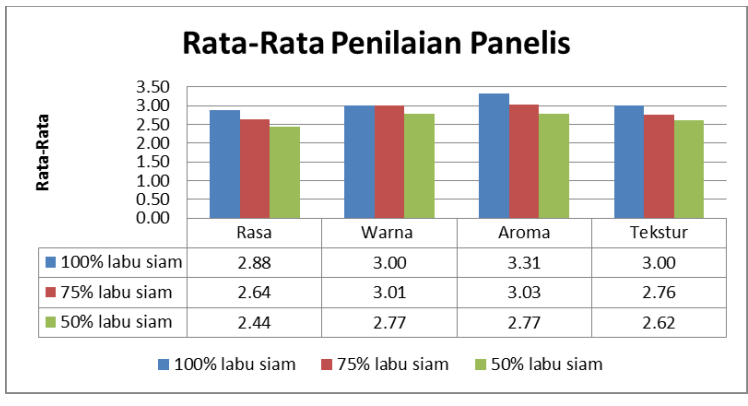

Gambar Hasil rata-rata Penilaian sumber : hasil uji hedonik panelis

Pada perlakuan LS1 menggunakan labu siam sebanyak $100 \%$, aspek Rasa mendapatkan nilai rata-rata sebesar 2.88 (kurang suka) dikarenakan labu siam memiliki rasa hambar yang membuat panelis kurang menyukai perlakuan. Aspek tekstur mendapatkan nilai ratarata sebesar 3,00 (suka) dikarenakan tekstur labu siam yang lembut dan ketika telah di olah serat dari labu siam akan tidak terlalu terasa. Aspek warna mendapatkan nilai rata-rata sebesar 3,00 (suka) di karenakan tekstur dari labu siam memiliki warnahijau muda dan olahan yang di buat menggunakan labu siam akan berwarna hijau cerah, salah satu penyebab mengapa banyak panelis yang menyukai perlakuan ini dari aspek warna di karenakan memiliki warna hijau yang cerah. Aspek aroma mendapatkan nilai rata-rata sebesar 3,31 (suka) di sebabkan oleh aroma dari labu siam tidak mempunyai aroma yang amis.

Perlakuan LS2 menggunakan labu siam sebanyak 75\%, aspek Rasa mendapatkan nilai rata-rata sebesar 2,64 (kurang suka) dikarenakan labu siam tidak memiliki rasa pahit dan mempunyai cita rasa yang enak dan kenyal. Rasa lembut muncul karena kandungan amilopektin yang terkandung dalam labu siam sangat tinggi, yang menyebabkan selai Rasa dodol pada perlakuan LS2 di gemari oleh panelis. Aspek tekstur mendapatkan nilai rata-rata sebesar 2,76 (kurang suka) dikarenakan tekstur labu siam yang kurang kenyal dan ketika telah di olah serat dari labu siam akan semakin halus dan ketika labu siam dimasak maka akan membuat tekstur dodol menjadi kurang kenyal. Aspek warna 
mendapatkan nilai rata-rata sebesar 3,01 (suka) di karenakan warna dari labu siam memiliki warna hijau muda namun setelah di olah dengan meggunakan perlakuan LS2 warna hijua dari labu siam manis tetap dominan dan Membuat warna dodol menjadi hijau.

Namun perlakuan LS2 dari aspek warna tidak sebanding dari perlakuan LS1 dikarenakan komposisi labu siam yang di gunakan di perlakuan LS2 lebih sedikit di bandingkan perlakuan LS1. Aspek aroma mendapatkan nilai rata-rata sebesar 3,03 (suka) dikarenakan aroma labu siam tidak mempunyai aroma yang menyengat, yang menyebabkan penilaian aspek aroma pada setiap perlakuan tidak jauh berbeda.

Perlakuan LS3 menggunakan labu siam sebanyak $50 \%$, aspek Rasa mendapatkan nilai rata-rata sebesar 2,44 (kurang suka) dikarenakan labu siam sendiri memliki rasa yang tidak manis dan tidak pahit, nilai yang di proleh dari perlakuan LS3 dari aspek rasa tidak jauh berbeda dari perlakuan LS2 yang di karenakan komposisi labu siami tidak melebihi komposisi LS3. Aspek tekstur mendapatkan nilai rata-rata sebesar 2,62 (kurang suka) dikarenakan tekstur labu siam yang kurang kenyal dan ketika telah di olah serat dari labu siam akan semakin kurang halus dan ketika labu siam dimasak maka akan membuat tekstur dodol menjadi kurang kenyal. Aspek warna mendapatkan nilai rata-rata sebesar 2,77 (kurang suka) di karenakan warna dari labu siam memiliki warna hijau cerah, namun setelah di olah dengan meggunakan perlakuan LS3 warna hijau muda dari labu siam tetap dominan dan membuat warna dodol menjadi hijau. Namun perlakuan LS3 dari aspek warna tidak sebanding dari perlakuan LS1 dikarenakan komposisi labui siam yang di gunakan di perlakuan LS3 lebih sedikit di bandingkan perlakuan LS1. Aspek aroma mendapatkan nilai rata-rata sebesar 2,77 (kurang suka) dikarenakan aroma labu siam yang tidak terlalu berbeda, yang menyebabkan penilaian aspek aroma pada setiap perlakuan tidak jauh berbeda

\section{Strategi Pemasaran}

Strategi pemasaran yang digunakan adalah marketing mix atau 4P dengan penjabaran sebagai berikut:

1) Product merupakan fitur dan keunggulan dari produk yang dijual dan akan dikomunikasikan dengan masyarakat umum. Keunggulan produk ini terletak pada keunikan yaitu dodol yang berasal dari labu siam dan rasa, aroma, dan tekstur yang disukai masyarakat.

2) Place merupakan tempat melakukan pemasaran produk. Sebagai produk baru, cara paling efisien, adalah dengan memasarkan produk melalui media online. Pemasaran dilakukan melalui media social sehingga tidak diperlukan biaya pemasaran produk melalui toko.

3) Price adalah harga jual produk yang harus mampu bersaing dengan produk lain. Dodol dapat dikemas menjadi kemasan kecil dengan harga jual Rp.1.000 per bungkus dan kemasan besar dengan harga Rp.15.000 per bungkus.

4) Promotion adalah metode promosi yang dilakukan. Promosi dilakukan dengan memasang iklan berbayar di media social dan bekerja sama dengan selegram untuk membuat video iklan agar dapat viral.

\section{SIMPULAN DAN SARAN PENELITIAN SELANJUTNYA}

\section{Simpulan}

Adapun simpulan dari penelitian ini adalah sebagai berikut:

1) Daya terima masyarakat terhadap dodol berbahan dasar labu siam dari segi rasa, tekstur, aroma dan warna yaitu dilihat darii rekapitulasi hasil angket dengan nilai ratarata aspek yang paling tinggi. Panelis lebih cenderung memilih perlakuan LS1 dengan aspek aroma dengan nilaii rata-rata sebanyak 3,31 hal ini disebabkan karna aroma dari labu siam lebih mendominasi. Pada aspek rasa LS1 2,88 (kurang suka) dikarenakan labu siam memiliki rasa hambar yang membuat 
panelis kurang menyukai perlakuan. Pada perlakuan LS1 aspek tekstur mendapatkan nilai rata-rata sebesar 3,00 (suka) dikarenakan tekstur labu siam yang lembut dan ketika telah di olah serat dari labu siam akan tidak terlalu terasa. Pada perlakuan LS2 Aspek warna mendapatkan nilai rata-rata sebesar 3,01 (suka) dii karenakan warna dari labu siam memiliki warna hijau muda namun setelah di olah dengan meggunakan perlakuan LS2 warna hiju dan labu siam manis tetap dominan dan membuat warna dodol menjadi hijau. Dari tiga perlakuan yang dilakukan oleh penulis dapat disimpulkan bahwa panelis lebih menyukai perlakuan LS 1 dari segi aspek rasa, aroma, tekstur dan aroma pada perlakuan LS 2

2) Strategi pemasaran yang dilakukan untuk memperkenalkan prroduk ini adalah marketing mix atau 4P, yaitu product, place, price, dan promotion.

\section{DAFTAR PUSTAKA}

Caya Khairani, A. D, 2012, Pengolahan Buahbuahan, Palu : Agro Inovasi.

Fatma, 2015, eksperimen pembuatan dodol labu kuning.

Gusman, 2013, pengujian organoleptik.

Kusumawati, M, 7 september 2015, Gula Pasir.

Mahmud, M. K, 14 mei 2014, diterbitkan Elex Media Komputindo : Kompas Gramedia, tersedia di http://www.worldcat.org/title/tabelkomposisi-pangan-indonesiatkpi/oclc/315241696.

Margaretha, E. d, 2012, Kualitas Makanan http://hortikultura.pertanian.go.id/wpconte nt/uploads/2016/02/Statistik-Produksi2014

STATISTIK PRODUKSI HORTIKULTURA, 2015 , http://hortikultura.pertanian.go.id/wpconte nt/uploads/2016/02/Statistik-Produksi2014
Sugiyono, P. D, 2015, Metode Penelitian Tindakan Komperehensif. Bandung: Alfabeta.

Sugiyono, P. D., 2016, Metode Penelitian dan Pengembangan R\&D. Bandung: Alfabeta.

SNI, S. N, 2015, di terbitkan badan standarisasi nasional, tersedia di http://sisni.bsn.go.id/index.php/sni_main/s ni/detail_sni/3378.

Yoesman, 2014, Pengaruh Gula Bagi Kesehatan Manusia, Bandung: Alfabeta. 